\title{
Effects of phenol, glycerin and acetic acid on the liver of guinea pigs ${ }^{1}$
}

\author{
Efeitos da soluçao de fenol, glicerina e ácido acético em figado de cobaias
}

\author{
Rogério Saad-Hossne², William Saad Hossne³ ${ }^{3}$ Mario Rubens Guimarães Montenegro ${ }^{4}$ \\ 1. Research performed at "William Saad Hossne” Laboratory of Experimental Surgery, Botucatu School of Medicine, State University of São Paulo \\ (UNESP), Brazil. \\ 2. PhD, Assintant Professor, Department of Surgery, Botucatu School of Medicine, UNESP, Brazil. \\ 3. Professor Emeritus, Botucatu School of Medicine, UNESP, Brazil. \\ 4. Professor Emeritus, In memoriam, Botucatu School of Medicine, UNESP, Brazil.
}

\begin{abstract}
Purpose: To investigate the histolytic action of a solution composed of phenol, glycerin and acetic acid for irresectable hepatic metastasis. Methods: Thirty-two (n=32) guinea pigs were randomly distributed into two groups of 16 animals. The animals in group 1 (experimental) and group 2 (control) were redistributed in two subgroups of eight animals each, according to the day of sacrifice (24 hours and four weeks after injection). All the animals were submitted to median laparotomy, which was followed by the injection of solution $\mathrm{E}$ and saline into the livers of subjects in both the experimental and control groups, respectively. The animals were evaluated for biochemical and anatomopathological (liver) alterations after 24 hours and four weeks of the experiment. Results: It was observed that solution E produced necrosis limited to the injected area and that hepatic tissue recovery occurred after four weeks with the formation of a small necrosis area. No biochemical parameters were altered either in the experimental or in the control group. Conclusion: In view of the obtained results, the possibility of using the proposed solution can be considered in cases of irresectable metastasis.
\end{abstract}

Key words: Acetic Acid. Phenol. Glycerol. Liver. Guinea pigs.

\section{RESUMO}

Objetivo: Investigar a ação histolítica da solução composta de fenol, glicerina e ácido acético para os casos de metástases hepáticas não ressecáveis. Métodos: Foram utilizadas 32 cobaias, distribuídas, por sorteio, em quatro grupos: experimental (24 horas e quatro semanas) e controle (24 horas e quatro semanas); todos os animais foram submetidos a laparotomia mediana e realizada a injeção da solução E (grupo experimental) ou solução fisiológica (grupo controle). Foram estudadas as alterações bioquímicas e anatomopatológicas (fígado) com 24 horas e quatro semanas de evolução. Resultados: Verificou-se que a solução E produz necrose delimitada à área infiltrada apos 24 horas e que ao final de quatro semanas ocorreu regeneração do tecido hepático com formação de discreta área de fibrose. Não foram observadas quaisquer alterações bioquímicas tanto no grupo experimental como controle. Conclusão: Frente aos resultados obtidos, é válido considerar-se a possibilidade do emprego da solução proposta, nos casos de metástases hepáticas não ressecáveis.

Descritores: Acido acético. Fenol. Glicerol. Fígado. Cobaias.

\section{Introduction}

During surgical procedures, surgeons frequently face limited possibilities of therapeutic action due to the infeasibility of neoplastic tissue total resection, such as when various visceral metastases, and hepatic metastases in particular, exist ${ }^{1,2}$. The major therapeutic modalitites presently used in the treatment of hepatic metastases are: surgical resection, artery ligation, embolization and chemotherapy, ablation methods (laser, radiofrequency, cryotherapy, hyperthermia, microwaves, and necrotizing and cytolytic substances) and genetic therapy ${ }^{3,4}$. To this date, surgical resection, the major therapeutic modality, is the only procedure that may result in cure. Nevertheless the number of patients capable of undergoing surgery (10-15\%) is low ${ }^{2}$. Among palliative methods, the ablative approach is distinguished as it uses cytolytic and necrotizing substances such as alcohol or other methods, namely, cryotherapy, radiofrequency, laser and microwaves for localized lesion destruction. These methods are most frequently applied in irresectable cases ${ }^{5}$. It was in this setting (destruction of irresectable metastases) that our line of investigation was developed. The basic idea was to try to destroy tumoral tissue by the use of solutions or substances with 
cytolytic or sclerosing action. Through literature review, it was verified that the injection of a solution composed of phenol, glycerin and glacial acetic acid into the prostate of dogs led to the reduction of that organ's volume, and that such reduction would be due to tissue necrosis ${ }^{6}$. The use of the solution was experimentally assayed in Walker's tumor hepatic metastases, leading to suggestive results of necrosis production without alterations in the clinical development of the tumor ${ }^{7,8}$. In face of such characteristic difficulties posed by hepatic metastasis therapy, new treatments must be developed with the purpose to achieve good efficacy rates, low cost, low frequency of side effects and easy execution. Hence, experimentally investigating the possibility of using such substance (henceforth referred to as solution E) in the destruction of irresectable hepatic metastases is considered to be a worthwhile undertaking.

\section{Methods}

Thirty-two male and female guinea pigs weighing 150 to $450 \mathrm{~g}$ were used. Prior to each experimental time, the guinea pigs were kept in fast for 8 hours with water provision ad libitum. Solution $\mathrm{E}$ was injected into the animals' livers and sacrifice occurred after 24 hours (group 1) or 4 weeks (group 2). Saline solution was injected into the animals comprising the control group and their sacrifice took place after 24 hours (group 3) or 4 weeks (group 4). Eight animals were used in each group, and euthanasia was performed by a lethal dose of anesthetic. The sclerosing solution was composed of phenol (0.6g), glycerin $(1.2 \mathrm{~g})$ and glacial acetic acid (0.6g) in distilled-water solution (28.0ml), denominated solution E. Based on a pilot experiment, the use of $0.5 \mathrm{ml}$ of the solution was selected. The same volume of saline solution (F) was used for the control groups. A dose of nembutal, 33mg/kg of weight, was intrapleurally administered. Median laparotomy with 3 to $4 \mathrm{~cm}$, beginning right under the xiphoid appendix, was performed for hepatic injection. Injection was always accomplished into the upper left lobe using an insulintype syringe with a $13 \times 4$ needle. Biochemical dosing was performed after the collection of $5 \mathrm{ml}$ of blood by heart puncture. Blood was collected immediately prior to anesthesia and euthanasia. The methodology used was as follows: glycemia - GOP-PAP test - Automation - ABRA - 100 - Reactoclinic Kit; alkaline phosphatase - (Alk. F). Spectrophotometer - Kinetic UV test - Automation - ABRA - 100 - Reactoclin kit; bilirubins (Bd, Bi, Bt). MALLOY-EVELYN method - Manual - the laboratory's own kit; glutamic oxalacetic transminase (GOT) - Kinetic UV test - Automation - ABRA - 100 - Reactoclìnic Kit; glutamic pyruvic transaminase (GPT) - Kinetic UV test - Automation - ABRA - 100 - Kit and gamma glutamyl transferase (Gamma GT) - Kinetic UV - Automation ABRA-100-Reactoclinic Kit. After sacrifice, the animal's abdomen was opened in the median line; the liver was macroscopically examined, and slides were prepared and stained by hematoxilin for histopathological examination. Slide reading was performed without previous knowledge of the group to which they belonged.

\section{Results}

\section{Chemical dosage}

Allthedosageamountsforglycemia, gamma-t, alkaline phosphatase, bilirubins, aspartate aminotranspherase and alanine aminotranspherase were within reference values, thus showing no statistically significant difference in any of the dosages at the different studied moments ( $>>0.05)$. When the individual values for each animal in the experimental group were compared, it was not possible to find alterations pointing to group tendency. Also, no alterations were found between the groups receiving solution $\mathrm{E}$ and those receiving saline solution (F).

\section{Clinical assessment - macroscopic examination}

The following phenomena were observed on the occasion of hepatic injection:

- No animals showed alterations in vital signs for and up to 5 minutes after injection of both solution $\mathrm{E}$ and saline solution.

- In the case of saline solution, the occurrence of a small pale area was observed around the puncture needle during injection, which was immediately followed by normalization upon completion of the procedure.

- In the case of solution E, a whitish area of approximately $1 \mathrm{~cm}$ was formed around the infiltration site.

Twenty-four hours later, no abnormal characteristics were observed in the animals receiving saline solution whereas those given solution $\mathrm{E}$ showed the presence of a white area of approximately $0.5 \mathrm{~cm}$ in diameter with necrotic appearance which was well circumscribed and presented no laceration or bleeding. After four weeks, some animals (5) showed a small whitish mark on the site of injection of solution E. No abnormal signs were found in the others.

\section{Histopathology}

Small focal areas were found with hepatocyte basophilia on virtually all liver slides from all groups. Although less frequently, points of lymphoid infiltrate were also observed in the portal spaces, which was not observed in the treated animals, however. Additionally, some of the animals presented variable and, in general, low-intensity levels of micro steatosis. The presence of steatosis did not vary whereas the periportal inflammatory infiltrate occurred only after 4 weeks, although with similar frequency in the experimental and control groups, 
which showed that such alteration was not related to the experiment, but probably dependent on other factors. Based on the microscopic assessment, only the animals sacrificed after 24 hours and which had been given hepatic infiltration with solution $\mathrm{E}$ presented focal-type necrosis (Figure 1). After 4 weeks, only 2 animals were observed to show a fibrosis focal area corresponding to the scar seen under macroscopy. In summary, the solution produced focal liver necrosis which was repaired after 4 weeks and left minimum scars. No other histological alterations that could be attributed to the action of solution $\mathrm{E}$ by the sclerosing substance were found.

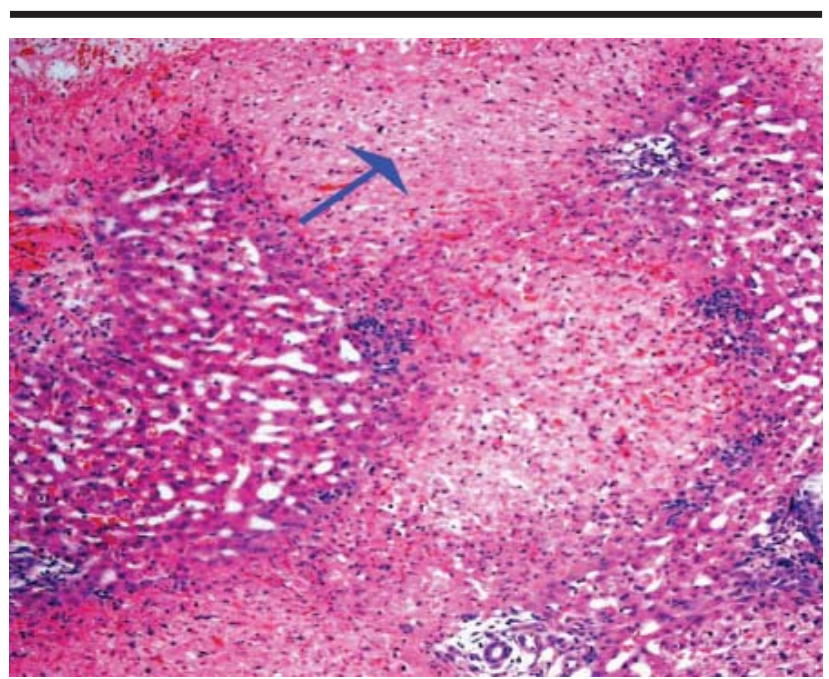

FIGURE1 - Histological section of a guinea pig's liver 24 hours afterinjection of sclerosing solution(E). Necrosis area (blue arrow). X200.HE staining

TABLE 1 - Biochemical dosages. Absolute values in each animal. Group: Liver infiltration with solution E - 24 hours

\begin{tabular}{ccccccccc}
\hline MALE & $\begin{array}{c}\text { GLYCEMIA } \\
\text { mg/dL }\end{array}$ & $\begin{array}{c}\text { ALK. } \\
\mathrm{U} / \mathrm{L}\end{array}$ & $\begin{array}{c}\mathrm{Bd} \\
\mathrm{Mg} / \mathrm{dL}\end{array}$ & $\begin{array}{c}\mathrm{Bi} \\
\mathrm{mg} / \mathrm{dL}\end{array}$ & $\begin{array}{c}\mathrm{Bt} \\
\mathrm{mg} / \mathrm{dL}\end{array}$ & $\begin{array}{c}\text { GOT } \\
\mathrm{U} / \mathrm{L}\end{array}$ & $\begin{array}{c}\text { GPT } \\
\mathrm{U} / \mathrm{L}\end{array}$ & $\begin{array}{c}\mathrm{gGt} \\
\mathrm{U} / \mathrm{L}\end{array}$ \\
\hline 1 & 143 & 56 & 0.02 & 0.10 & 0.12 & 121 & 95 & 17 \\
2 & 126 & 73 & 0.01 & 0.15 & 0.16 & 127 & 89 & 19 \\
3 & 127 & 97 & 0.02 & 0.12 & 0.14 & 150 & 92 & 15 \\
4 & 127 & 69 & 0.01 & 0.10 & 0.11 & 38 & 78 & 14 \\
\hline FEMALE & & & & & & & & 70 \\
\hline 5 & 152 & 99 & 0.03 & 0.10 & 0.13 & 106 & 24 \\
6 & 118 & 69 & 0.01 & 0.10 & 0.11 & 102 & 70 & 15 \\
7 & 148 & 100 & 0.03 & 0.15 & 0.18 & 90 & 160 & 15 \\
\hline Mean & 151 & 89 & 0.03 & 0.13 & 0.36 & 76 & 120 & 15 \\
\hline
\end{tabular}

TABLE 2 - Biochemical dosages. Absolute values in each animal. Group: liver infiltration with solution E - 4 weeks

\begin{tabular}{lcccccccc}
\hline MALE & $\begin{array}{c}\text { GLYCEMIA } \\
\text { mg/dL }\end{array}$ & $\begin{array}{c}\text { ALK. } \\
\mathrm{U} / \mathrm{L}\end{array}$ & $\begin{array}{c}\mathrm{Bd} \\
\mathrm{Mg} / \mathrm{dL}\end{array}$ & $\begin{array}{c}\mathrm{Bi} \\
\mathrm{mg} / \mathrm{dL}\end{array}$ & $\begin{array}{c}\mathrm{Bt} \\
\mathrm{mg} / \mathrm{dL}\end{array}$ & $\begin{array}{c}\text { GOT } \\
\mathrm{U} / \mathrm{L}\end{array}$ & $\begin{array}{c}\text { GPT } \\
\mathrm{U} / \mathrm{L}\end{array}$ & $\begin{array}{c}\mathrm{gGt} \\
\mathrm{U} / \mathrm{L}\end{array}$ \\
\hline 1 & 155 & 69 & 0.01 & 0.10 & 0.11 & 118 & 77 & 15 \\
2 & 138 & 73 & 0.02 & 0.13 & 0.15 & 108 & 73 & 19 \\
3 & 153 & 59 & 0.02 & 0.12 & 0.14 & 36 & 132 & 15 \\
4 & 197 & 92 & 0.02 & 0.10 & 0.12 & 79 & 97 & 11 \\
\hline FEMALE & & & & & & & \\
\hline 5 & 138 & 61 & 0.01 & 0.10 & 0.11 & 113 & 75 & 16 \\
6 & 143 & 98 & 0.01 & 0.10 & 0.11 & 68 & 93 & 14 \\
7 & 153 & 69 & 0.01 & 0.09 & 0.10 & 45 & 102 & 15 \\
8 & 150 & 67 & 0.01 & 0.09 & 0.10 & 45 & 101 & 15 \\
\hline Mean & 153 & 73 & 0.01 & 0.10 & 0.12 & 76 & 93 & 15 \\
\hline
\end{tabular}


TABLE 3 - Biochemical dosages. Absolute values in each animal. Group: Liver infiltration with saline solution - 24 hours

\begin{tabular}{ccccccccc}
\hline MALE & $\begin{array}{c}\text { GLYCEMIA } \\
\text { mg/dL }\end{array}$ & $\begin{array}{c}\text { ALK. } \\
\mathrm{U} / \mathrm{L}\end{array}$ & $\begin{array}{c}\mathrm{Bd} \\
\mathrm{Mg} / \mathrm{dL}\end{array}$ & $\begin{array}{c}\mathrm{Bi} \\
\mathrm{mg} / \mathrm{dL}\end{array}$ & $\begin{array}{c}\mathrm{Bt} \\
\mathrm{mg} / \mathrm{dL}\end{array}$ & $\begin{array}{c}\text { GOT } \\
\mathrm{U} / \mathrm{L}\end{array}$ & $\begin{array}{c}\text { GPT } \\
\mathrm{U} / \mathrm{L}\end{array}$ & $\begin{array}{c}\mathrm{gGt} \\
\mathrm{U} / \mathrm{L}\end{array}$ \\
\hline 1 & 121 & 17 & 0.03 & 0.07 & 0.10 & 84 & 27 & 17 \\
2 & 113 & 11 & 0.01 & 0.09 & 0.11 & 115 & 42 & 16 \\
3 & 168 & 22 & 0.07 & 0.03 & 0.12 & 86 & 36 & 8 \\
4 & 118 & 18 & 0.05 & 0.05 & 0.10 & 21 & 39 & 22 \\
\hline FEMALE & & & & & & & 73 \\
\hline 5 & 117 & 16 & 0.06 & 0.04 & 0.10 & 119 & 73 \\
6 & 118 & 10 & 0.02 & 0.08 & 0.08 & 105 & 181 & 17 \\
7 & 103 & 4 & 0.04 & 0.06 & 0.10 & 115 & 117 & 9 \\
8 & 113 & 7 & 0.04 & 0.06 & 0.09 & 94 & 156 & 6 \\
\hline Mean & 121 & 11 & 0.04 & 0.06 & 0.10 & 92 & 84 & 13 \\
\hline
\end{tabular}

TABLE 4 - Biochemical dosages. Absolute values in each animal. Group: Liver infiltration with saline solution - 4 weeks

\begin{tabular}{ccccccccc}
\hline MALE & $\begin{array}{c}\text { GLYCEMIA } \\
\text { mg/dL }\end{array}$ & $\begin{array}{c}\text { ALK. P. } \\
\mathrm{U} / \mathrm{L}\end{array}$ & $\begin{array}{c}\mathrm{Bd} \\
\mathrm{Mg} / \mathrm{dL}\end{array}$ & $\begin{array}{c}\mathrm{Bi} \\
\mathrm{mg} / \mathrm{dL}\end{array}$ & $\begin{array}{c}\mathrm{Bt} \\
\mathrm{mg} / \mathrm{dL}\end{array}$ & $\begin{array}{c}\mathrm{GOT} \\
\mathrm{U} / \mathrm{L}\end{array}$ & $\begin{array}{c}\mathrm{GPT} \\
\mathrm{U} / \mathrm{L}\end{array}$ & $\begin{array}{c}\text { gGt } \\
\mathrm{U} / \mathrm{L}\end{array}$ \\
\hline 1 & 105 & 8 & 0.03 & 0.07 & 0.10 & 127 & 52 & 11 \\
2 & 81 & 9 & 0.07 & 0.13 & 0.20 & 152 & 95 & 10 \\
3 & 96 & 6 & 0.04 & 0.06 & 0.10 & 195 & 130 & 16 \\
4 & 98 & 6 & 0.05 & 0.06 & 0.12 & 250 & 124 & 15 \\
\hline
\end{tabular}

FEMALE

\begin{tabular}{lllllllll}
\hline 5 & 109 & 10 & 0.03 & 0.07 & 0.10 & 104 & 18 & 9 \\
6 & 100 & 9 & 0.06 & 0.06 & 0.10 & 150 & 120 & 12 \\
7 & 130 & 11 & 0.06 & 0.06 & 0.11 & 25 & 23 & 23 \\
8 & 115 & 11 & 0.08 & 0.08 & 0.10 & 56 & 25 & 11 \\
\hline Mean & 104 & 9 & 0.05 & 0.07 & 0.11 & 132 & 73 & 13 \\
\hline
\end{tabular}

\section{Discussion}

Guinea pigs were used as experimental animals due to the fact that such animals are very sensitive to drug effects $^{8}$. Also, the type of anesthesia administered must be pointed out. Since venous anesthesia was not possible, and considering that ether anesthesia had led to complications as well as that the peritoneal route was not indicated due to occasional interference with the drug being tested, the use of the intrathoracic route was standardized with good results. No references to the use of such route in guinea pigs were found in the literature. A dose of $0.5 \mathrm{ml}$ of solution was standardized since it enabled the definition of an appropriate area in the liver immediately after injection. As regards body weight, the dose corresponded to 1.0 to $1.5 \mathrm{ml} / \mathrm{Kg}$ of the animal's weight. Phenol, one of the solution's components, features antiseptic (shown by Lister in the 19th century) and anesthetic action. Phenol's germicidal histotoxic action results from protein denaturation $^{9,10}$. According to Goodman and Gilman ${ }^{10}$, the solution of phenol in glycerin is less active than the aqueous solution as they report that its oral ingestion may cause mucocutaneous and gastrointestinal corrosion. In humans, phenol, at a dose of $4 \mathrm{~g}$, causes intoxication, and a dose of 15 to $20 \mathrm{~g}$ may lead to death ${ }^{9,10}$. Systemic toxicity ${ }^{10}$ is shown by the transitory stimulation of the CNS, and the carcinogenic potential of phenol is disputable, according to those authors. Phenol is mainly eliminated by the kidneys, and most of it is excreted in the first 24 hours $^{11}$. Glacial acetic acid also features bactericidal action when the 5\% solution in smaller concentrations is bacteriostatic ${ }^{10}$. In mice, the DL50 dose is $5 \mathrm{~g} / \mathrm{Kg}$ of weight. In humans, a lethal dose is of 15 to $30 \mathrm{~g}$ of pure acid or $300 \mathrm{ml}$ of $5 \%$ solution $^{10,11}$. Glycerin also has diuretic action (osmotic diuretics) and is quickly metabolized. The dose for adults is of 1 to $1.5 \mathrm{~g} / \mathrm{Kg}$ of weight. A daily dose must not exceed $120 \mathrm{~g}^{10}$. In mice, its lethal dose is $31.58 \mathrm{~g} / \mathrm{kg}$ of weight when orally administered or $7.56 \mathrm{~g} / \mathrm{Kg}$, if it is venously injected. It is known that glycerin has renal vasoconstricting action (in higher doses) and may produce renal insufficiency. Solution E, containing such components, was empirically used, as previously mentioned, for protatic patients in the early $21^{\text {st }}$ century in India by Roberts ${ }^{6}$. Since then, it has been used by other authors, but always in the prostate $e^{6,12}$. No other similar studies to ours were found in the literature and neither were references to biochemical dosages in animals noted so as to enable comparison to our findings. 
Alterations between the animals in the treated and control groups were not observed. The experimental groups were analyzed at 24 hours and at 4 weeks of development, since in a pilot experiment, it was observed that after 24 hours, the infiltrated area presented rather visible necrosis, and that after 4 weeks, it would be possible to verify whether replacement by fibrous or by hepatic tissue had occurred. Our results showed that the injection of solution E into the liver did not lead to biochemical alterations related to the hepatic function. From the histopathological point of view, the injection of solution E caused a necrosis area in the infiltrated region which was perfectly diagnosed (macro and microscopically) after 24 hours. After 4 weeks of development, necrosis was not shown, and the liver presented normal appearance during both the macroscopic and the microscopic examination; the necrosis area was replaced (only in two animals) by a small extension of minor fibrotic tissue, and normal hepatic tissue was recovered.

The injection of saline solution was not followed by any anatomopathological alterations. Based on the obtained results, it is believed that the possibility of infiltrating hepatic metastases with solution $\mathrm{E}$ is feasible. Through such procedure, it would be possible to destroy neoplastic cells by necrosis: the occasional destruction of hepatic tissue near the tumoral area, after a certain period of time, will probably show recovery of normal tissue with a small cicatricial area (at times).

\section{Conclusion}

In guinea pigs, the used dose $(0.5 \mathrm{ml})$ of the sclerosing solution (E), when infiltrated into the liver:

1. produces necrosis.

2. necrosis is focal, limited to the infiltrated area.

3. it is not followed by clinical alterations in the animal and does not cause mortality.

4. it is not followed by biochemical alterations related to the hepatic function.

5. recovery of hepatic tissue with mild fibrosis occurs after necrosis.

6. it is not followed by clinical alterations and no mortality takes place.
Based on these conclusions of experimental nature, the perspective of using solution $\mathrm{E}$ in the treatment of irresectable hepatic metastases is recommended.

\section{References}

1. Adam R. Colorectal cancer with synchronous liver metastases. Br J Surg. 2007;94:129-31.

2. Schlag PM, Benhidjeb T, Kilpert B. Surgical and multimodality treatment of colorectal liver metastases. Onkologie. 1999;22:92-7.

3. Filippone A, Iezzi R, Di Fabio F, Cianci RD, Grassedonio E, Storto ML. Multidetector-row computed tomograpy of focal liver lesions treated by radiofrequency ablation: spectrum of findings at long-term follow-up. J Comput Assist Tomogr. 2007;31:42-52.

4. Krishnan S, Lin EH, Gunn GB, Brandon BS, Chandra A , Beddar AS, Briere TM, Das P, Delclos ME, Janjan NA, Crane CH. Conformal radiotherapy of the dominant liver metastasis: a viable strategy for treatment of unresectable chemotherapy refractory colorectal cancer liver metastases. Am J Clin Oncol. 2006;29:562-67.

5. Beaugrand M, N'kontchou G, Seror O, Ganne N, Trinchet J-C. Local/regional and systemic treatments of hepatocellular carcinoma. Semin Liver Dis. 2005;25:201-11.

6. Talmar GL, Pande SK. Injection tratament of enlarged prostate. Br J Surg. 1966;53:421-7.

7. Camara FR. Injeção prostática de solução esclerosante. Estudo experimental no cão [Tese] - Faculdade de Medicina de Botucatu; 1973.

8. Macedo AR, Faifer JG, Hossne WS. Risulti della terapia sclerosante locale nel trattamento del carcinosarcoma di walker 256 unouabtato nel figato. Chir Patol Sper. 1979;27:444-55.

9. Calabrese AI, Astolfi EA. Toxicologia. Buenos Aires: Kapeluz; 1969.

10. Goodman LS, Gilman AG. The pharmacological basis of therapeutics. 10ed. New York: McGraw-Hill; 2002.

11. Bailão N. Intoxicação exógenas agudas. In: Corbett CE. Elementos de farmacodinâmica. 2ed. São Paulo: Altas Médicas; 1966.

12. Shipman JJ, Akilie AN. Tratment by prostatic injection of acute urinary retention due to prostatic hiperplasia. Br Med J. 1967;2:416-9.

\section{Correspondence:}

Rogério Saad Hossne

Unesp - Botucatu, Campus

District Rubião Junior

18618-000 Botucatu - São Paulo Brazil

saad@fmb.unesp.br
Conflict of interest: none Financial source: none

Received: April 10, 2007

Review: June 12, 2007

Accepted: July 18, 2007

\section{How to cite this article}

Saad-Hossne R, Saad-Hossne W, Montenegro MRG. Effects of phenol, glycerin and acetic acid on the liver of guinea pigs. Acta Cir Bras. [serial on the Internet] 2007 Nov-Dec;22(6). Available from URL: http://www.scielo.br/acb 